\title{
Rainbow trout Oncorhynchus mykiss energetic responses to pulsed flows in the American River, California, assessed by electromyogram telemetry
}

\author{
Sarah A. Cocherell • Dennis E. Cocherell • Gardner J. Jones • Javier B. Miranda • \\ Lisa C. Thompson • Joseph J. Cech Jr. • A. Peter Klimley
}

Received: 1 October 2009 / Accepted: 12 August 2010/Published online: 1 September 2010

(C) The Author(s) 2010. This article is published with open access at Springerlink.com

\begin{abstract}
Although rainbow trout Oncorhynchus mykiss within the American River, California, apparently exhibit minimal upstream or downstream movements in response to hydroelectric-power-generation-related pulsed flows, the associated energetic costs are unknown. We implanted rainbow trout $(n=9, \geq 30 \mathrm{~cm} \mathrm{SL})$ with electromyogram (EMG)-sensor-equipped radio transmitters to assess the swimming behavior and associated energetic costs associated with their responses to pulsed flows. Using laboratory calibrations in a Brett-type swimming respirometer, the trouts' swimming speeds and oxygen consumption rates were estimated for their in-river EMG data, through a complete hydroelectric power-generation river pulsedflow sequence (pre-pulse, increasing flow, peak, and decreasing flow stages), on several (mean: 3.2) sampling dates. Using a mixed-linear model, we found that
\end{abstract}

S. A. Cocherell • D. E. Cocherell • G. J. Jones •

J. B. Miranda • L. C. Thompson $(\bowtie) \cdot$ J. J. Cech Jr. •

A. P. Klimley

Wildlife, Fish, \& Conservation Biology Department, University of California Davis,

1 Shields Avenue,

Davis, CA 95616-8751, USA

e-mail: 1cthompson@ucdavis.edu

Present Address:

G. J. Jones $\cdot$ J. B. Miranda

California Department of Water Resources,

1416 9th Street, Room 252-35,

Sacramento, CA 95814, USA fish swimming speed estimates increased during the increasing flow stage, while the associated mean oxygen consumption rates also increased at this stage. At river flows near the usual peak $\left(>44 \mathrm{~m}^{3} \mathrm{~s}^{-1}\right)$, swimming speeds and movement rates decreased, possibly due to the fish using the river's habitat complexities as hydraulic cover. We conclude that rainbow trout incur increased swimming-related energetic costs during increasing flows and, potentially, decreased foraging opportunities at high flows.

Keywords American river Pulsed flows . Hydroelectric · Electromyogram · Radio telemetry . Rainbow trout

\section{Introduction}

Human-controlled pulsed flows are common within many regulated rivers, but their effects on aquatic communities are relatively unknown. Anthropogenic water discharge pulses result from generating electricity, flushing streambeds, and providing human recreational (e.g., whitewater rafting) opportunities. Native Californian fish species have evolved with seasonal flow fluctuations (Moyle 2002), but their increased frequency and late-warm-season timing for recreational purposes during recent decades represent significant deviations from the natural hydrograph. Possible effects of these strong, pulsed flows on fishes 
could include their longitudinal displacement (e.g., forcing downstream) to suboptimal habitats, or increased metabolic costs (e.g., associated with faster swimming) to maintain position.

Klimley et al. (2007) found that two sizes of radiotelemetered rainbow trout Oncorhynchus mykiss were not consistently displaced downstream during daily hydro-electric-related pulsed flows in the South Fork of the American River. These trout may have maintained position through the use of areas with slower water velocities, such as in complex river margin habitats (Gido et al. 2000) or deeper pools (Bunt et al. 1999). Alternatively, they may have swum faster, consuming more oxygen and converting more metabolic energy (Webb 1971), to avoid nonvolitional displacement downriver and to maintain optimal-foraging positions. This added exercise might result in less energy being allocated to growth in both sexes or egg production in females (Jobling 1994).

Electromyograms (EMGs) are measurements of the electric potentials (voltages) in musculature, which are roughly proportional to the extent and duration of muscular exertion (Sullivan et al. 1963; Cooke et al. 2004). Thorstad et al. (2000) found that EMGs were highly positively correlated with the fish's swimming speed. Aerobic metabolism within the red (slowoxidative) muscles governs fish's oxygen demand at any particular temperature. Thus, it is likely that EMG generated by each myomere, and the activity of a whole segment of myomeres, will be closely correlated with their oxygen consumption rate (Weatherley et al. 1982). EMG telemetry has been used to determine the energetic cost of migration (Hinch and Rand 1998; Standen et al. 2002), the activity exhibited during pulses of flow in a regulated river (Murchie and Smokorowski 2004; Geist et al. 2005), passage through potential barriers such as weirs, dams, and rapids (Hinch et al. 1996; Quintella et al. 2004), and to identify spawning activity (Brown et al. 2006). For example, oxygen consumption rates inferred from EMGs showed that energy costs for sockeye salmon were highest during the dominant phases of the reproductive period and spawning (Healey et al. 2003). Brown and Geist (2002) employed EMG transmitters to show that energy use during migration was higher in tailraces than in forebays and fishways for adult Chinook salmon O. tshawystcha. A similar study by Standen et al. (2002) on the Fraser River revealed that pink salmon $O$. gorbuscha and sockeye salmon energy output peaked at river reaches that were constricted by mid-channel or point bars.

Our objective was to estimate the swimming speeds and energetic costs associated with exposure to daily pulsed flows for adult rainbow trout in the South Fork of the American River, California. We inserted intraperitoneal transmitters with electrodes that sensed electrical potentials when the lateral (aerobic, red) musculature contracted (EMG). By calibrating each individual's EMG outputs in the laboratory to its tail beat frequencies (TBF), swimming velocities, and its oxygen consumption rates in a swimming respirometer (Brett 1964; Lankford et al. 2005), their in-river swimming velocities and associated metabolic costs could be estimated during exposure to daily pulsed flows in the American River. This work was concurrent with our radio-tracking study in the same river reach of 20 additional rainbow trout (Klimley et al. 2007). From the minimal literature regarding such measurements (Murchie and Smokorowski 2004), we hypothesized that the trout's swimming speeds and energy costs would increase as river discharges increased to peak flows and that they would decrease as the river discharges decreased to pre-pulse levels.

\section{Methods}

Research subjects and field study site

In February 2005 healthy rainbow trout were obtained from the California Department of Fish and Game's American River Trout Hatchery (Rancho Cordova, California), which, historically, has planted rainbow trout into the American River watershed (Dill and Cordone 1997). Fish were transported (40 $\mathrm{min})$ in a large fiberglass tank filled with hatchery water, with continuous aeration, to the Center for Aquatic Biology and Aquaculture (CABA) on the University of California's Davis campus. At CABA, fish were held in large (555-1) round fiberglass tanks with continuous flows of aerated, non-chlorinated fresh water from a dedicated well.

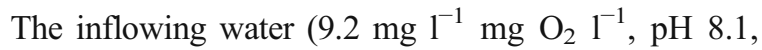
conductivity $690 \mu \mathrm{S} \mathrm{cm} \mathrm{cm}^{-1}$ ) produced a current of $<10 \mathrm{~cm} \mathrm{~s}^{-1}$ in the tank. Fish underwent a treatment regime of $200 \mathrm{ppm}$ formalin (static bath, $1 \mathrm{~h}$ ) followed (after 1-2 d) by $100 \mathrm{ppm}$ oxytetracycline (static bath, $2 \mathrm{~h}$ for $3 \mathrm{~d}$ ). One week after treatments the holding 
tank temperature was increased at $1{ }^{\circ} \mathrm{C} \mathrm{d}^{-1}$ from $12^{\circ} \mathrm{C}$ to $18-19^{\circ} \mathrm{C}$. Fish were fed semi-moist pellets (Rangen, Inc., Buhl, Idaho) daily to satiation.

Field studies were conducted in the South Fork American River (El Dorado County, CA). The rainbow trout release sites were Henningsen-Lotus County Park (river km: 12.9) or Camp Lotus camp site (river km: 14.5). The fish were subsequently tracked from Marshall Gold Discovery State Historic Park (river km: 9.7) to Gorilla Rock, just upstream of Fowler's Rock Rapid (river km: 25.8). This 12.9 km reach of the river is characterized by strong hydroelectric-associated pulsed flows from Chili Bar Dam (river km: 0) operated by Pacific Gas \& Electric, and it is a popular destination for whitewater rafting. The base water discharges from Chili Bar Dam were $5 \mathrm{~m}^{3} \mathrm{~s}^{-1}$. These discharges pulsed periodically to $35 \mathrm{~m}^{3} \mathrm{~s}^{-1}$ (most weekdays) or to $>45 \mathrm{~m}^{3} \mathrm{~s}^{-1}$ on many weekend days.

Transmitters and surgical procedures

The EMG radio transmitters (two types) each had two teflon-coated stainless-steel probes that led to goldplated electrodes that were embedded in the musculature of each fish to permit the detection of EMG signals (Hinch et al. 1996; Thorstad et al. 2000). The first type (Lotek, CEMG-R11-18, $54 \mathrm{~mm} \times 11 \mathrm{~mm}$ diameter) weighed $11 \mathrm{~g}$ in air, had a 56-d life span, and recorded the cumulative electrical activity in the trout's undulating body muscle (tail beats) over $5 \mathrm{~s}$ per single EMG output. The second (Lotek, CEMG-R11-25, $62 \mathrm{~mm} \times$ $11 \mathrm{~mm}$ diameter) weighed $12 \mathrm{~g}$ in air, had a 40-d life span, and recorded similar electrical activity over a 2-s period. The transmitters detected voltage oscillations ranging over a 1 to $150 \mu \mathrm{V}$ amplitude (Kaseloo et al. 1992). These electrical signals were integrated within the transmitter, which produced a non-dimensional EMG unit, ranging from 0 to 50 , related to muscle activity. EMGs were either recorded by hand after being displayed on a manual-tracking receiver (Lotek Wireless, SRX 400A or SRX 32) or logged to memory of a continuous, data-logging receiver (Lotek Wireless, SRX 600).

The surgical insertion of the transmitter in the peritoneum of trout was as described by Klimley et al. (2007) except for implantation of the electrodes in their red axial muscles. The gold-tipped electrodes of the EMG transmitters were placed into the trout's lateral, red-muscle bands (Bunt 1999). The electrodes were always placed in the same relative location, regardless of trout size, midway between the tips of the pectoral fins and base of the pelvic fins, just ventral and proximal to the lateral line, because electrode placement influences the strength of the recorded voltages (Beddow and McKinley 1999). We conducted identical procedures on pilot rainbow trout $(n=10)$ to test placement of the transmitters. The experience gained from these pilot fish helped assure that the electrodes were placed properly, in the red-muscle bands. Fish were allowed 3 to $13 \mathrm{~d}$ to recover from surgery before starting laboratory calibrations. Five of these trout (release group 1; RTE 1-5; 510 to 1,279 $\mathrm{g}$ mass and 30 to $39.5 \mathrm{~cm} \mathrm{SL}$ ) carried the first type of transmitter, while the other four (release groups 2 and 3; RTE 6-9; 1,600 to $2,083 \mathrm{~g}$ mass and 42.5 to $46 \mathrm{~cm} \mathrm{SL}$ ) carried the second type.

\section{Laboratory studies}

To ascertain whether either the surgical procedure or the added mass of the transmitter affected the swimming ability of the trout, we compared swimming performance without surgery and transmitters $\left(n=10 ; 19^{\circ} \mathrm{C}\right.$; mean \pm SE: SL $34.6 \pm 0.9 \mathrm{~cm}$, mass $874 \pm 88 \mathrm{~g}$ ) to fish with surgery and transmitters $\left(n=9\right.$; RTE $1-5$ at $19^{\circ} \mathrm{C}$ and RTE $6-9$ at $16^{\circ} \mathrm{C}$; mean \pm SE: SL $39.2 \pm 1.9 \mathrm{~cm}$, mass $1396.2 \pm 188 \mathrm{~g})$. Both the critical swimming velocity $\left(\mathrm{U}_{\text {crit }}\right)$, at which a fish can no longer maintain its place during increasing flows through a 655-1 Brettstyle-swimming chamber (Brett 1964), and the TBF were measured in strokes $\min ^{-1}$, and the means were compared using ANOVA statistics.

Individual trout were removed from their holding tanks, lightly anesthetized, using sodium bicarbonate activated by glacial acetic acid (Prince et al. 1995) to minimize handling stress and avoid dislodging the electrodes via excessive struggling, weighed, and measured before being placed in the respirometer. Fish were quickly revived and allowed to acclimate in the chamber for $15 \mathrm{~min}$ at a nominal $5 \mathrm{~cm} \mathrm{~s}^{-1}$ water velocity, followed by an additional $45 \mathrm{~min}$ at $10 \mathrm{~cm} \mathrm{~s}^{-1}$. The velocity was increased to $26.0 \mathrm{~cm} \mathrm{~s}^{-1}$ (ca 0.75 body length [bl] s${ }^{-1}$ ) at the beginning of the experiment followed by stepwise increases of $13.3 \mathrm{~cm} \mathrm{~s}^{-1}$ every $30 \mathrm{~min}$, the velocity increment approximating $0.25 \mathrm{bl} \mathrm{s}^{-1}$ (Hammer 1995; Beamish 1978). The trout's TBF was recorded at the 15,20 , and 
25-min times during each velocity and EMGs were recorded from the transmitter every minute.

Each experiment was terminated when the fish became fatigued. Fatigue was defined as when the fish impinged against the rear screen three times during one velocity or if the trout was in contact with the back screen for $3 \mathrm{~min}$ and would refuse to swim after the flow was stopped and restarted three times. The $\mathrm{U}_{\text {crit }}$ was calculated according to the equation:

$\mathrm{U}_{\text {crit }}=\mathrm{V}_{\mathrm{p}}+\left(\left(\mathrm{t}_{\mathrm{f}} / \mathrm{t}_{\mathrm{i}}\right) * \mathrm{~V}_{\mathrm{i}}\right)$,

where $V_{p}$ is the penultimate velocity at which the fish swam before fatigue $(\mathrm{cm} / \mathrm{s}), V_{i}$ is the velocity increment, $t_{f}$ is the elapsed time from velocity increase to fatigue, and $t_{i}$ is the time $(30 \mathrm{~min})$ of each velocity interval (Brett 1964). Fish were returned to their holding tanks after the $\mathrm{U}_{\text {crit }} / \mathrm{TBF}$ experiments.

Two days after the $U_{\text {crit }} / T B F$ experiments, the fish (RTE 1-9) with transmitters were re-introduced to the Brett-type swim-tunnel and metabolic oxygen consumption rates were measured to establish the relationships between oxygen consumption and the TBF and EMG data for individual fish (Brett 1964; Geist et al. 2002; Lankford et al. 2005). The fish were handled in the same manner as the $\mathrm{U}_{\text {crit }} / \mathrm{TBF}$ experiments at five water velocities $(26.0,39.3,52.6,65.9$, and $79.2 \mathrm{~cm} \mathrm{~s}^{-1}$ ). Beginning with $26.0 \mathrm{~cm} \mathrm{~s}^{-1}$ the swimming respirometer was sealed, and a water sample was taken at the beginning and end of each 30-min time period to determine its partial pressure of oxygen $\left(\mathrm{pO}_{2}\right)$. The $\mathrm{pO}_{2}$ was measured with a polarographic electrode (Model E101, Analytic System, Inc.) and calibrated $\mathrm{O}_{2}$ analyzer (PHM 71, Radiometer) and converted to $\mathrm{O}_{2}$ concentration $\left(\mathrm{CO}_{2}, \mathrm{mg} \mathrm{^{-1 }}\right)$ using the nomogram of Green and Carritt (1967). If the dissolved oxygen level in the chamber fell below $70 \%$ of air saturation, the chamber was flushed with air-saturated water (Hammer 1995). Swimming metabolic rate was calculated according to the equation:

$\mathrm{MO}_{2}=\left[\left(\mathrm{CO}_{2}(\mathrm{~A})-\mathrm{CO}_{2}(\mathrm{~B})\right) * \mathrm{~V}\right] / \mathrm{T}$,

where $\mathrm{MO}_{2}$ is $\mathrm{O}_{2}$ consumption rate $\left(\mathrm{mg} \mathrm{O}_{2} \mathrm{~h}^{-1}\right)$, $\mathrm{CO}_{2}(\mathrm{~A})$ is $\mathrm{O}_{2}$ concentration in water $\left(\mathrm{mg} \mathrm{O}_{2} \mathrm{l}^{-1}\right)$ at the start of the measurement period, $\mathrm{CO}_{2}(\mathrm{~B})$ is $\mathrm{O}_{2}$ concentration in water $\left(\mathrm{mg} \mathrm{O}_{2} \mathrm{l}^{-1}\right)$ at the end of the measurement period, $\mathrm{V}$ is the volume of the respi- rometer (l), and $\mathrm{T}$ is the time elapsed (h) during the measurement period (Cech 1990).

Finally, because American River temperatures decreased from summer conditions $\left(19^{\circ} \mathrm{C}\right)$, when the first six trout carrying transmitters were released for field assessments of pulsed-flow effects, to autumn (October) conditions $\left(16^{\circ} \mathrm{C}\right)$, the swimming and oxygen consumption experiments for the last four rainbow trout were conducted at $16^{\circ} \mathrm{C}$ instead of $19^{\circ} \mathrm{C}$. Fish were returned to their holding tanks after the $\mathrm{MO}_{2}$ experiments.

Field studies

After laboratory calibrations the trout were released and tracking commenced at 07:30-08:00 on one of three dates 26 August (group 1), 27 September (group 2), and 18 October 2005 (group 3, Table 1). This timing always preceded water releases, during the late-morning of the same day, from the Chili Bar Dam, producing the daily flow pulse. The number of weekly pulsed flows ranged from three to eight (daytime) and from two to four (nighttime), during the study period (Table 2). The river's mean daily water temperature typically did not exceed $20^{\circ} \mathrm{C}$ (FERC 2008) and ranged from 13 to $21.7^{\circ} \mathrm{C}$ during the summer along our study reach (PGE 2005).

Range tests were conducted for one of each transmitter type, to relate their signal strengths to detection distances. Both range tests were conducted at the same location, Henningsen-Lotus County Park with at least three measurements at each distance interval. The range test of the two tag types, when regressing signal power $(\mathrm{x})$ versus distance $(\mathrm{y})$, yielded: $y=250.05-2.02 \mathrm{x}, \mathrm{r}^{2}=0.758$ for $5 \mathrm{~s}$ and $y=$ 235.22-3.09x, $\mathrm{r}^{2}=0.773$ for $2 \mathrm{~s}$ transmitters.

When in radio contact with a fish, its location was determined every 60 min based on the transmitter's signal power. When the signal power for the tag was $>180$, we recorded a GPS location, habitat (main channel, river margin, or back-water area), signal power strength, and physical features of the reach. Transmitter signal strength vs. distance calibration regressions were combined with the GPS accuracy to calculate the amount of error associated with each fish's location. EMG data were either recorded manually at 60 measurements per $10 \mathrm{~min}$ period every $30 \mathrm{~min}$ or logged in the receiver.

The three-person tracking crew remained, typically, with the individual fish being tracked for the four 
Table 1 Days when rainbow trouts' EMGs were recorded during the daily pulsed flows. Dates in bold denote fish group release days. Chronological numbering system refers to the sequence of days each individual trout was tracked; 1 referring to the first day tracked, 2 to the second day of tracking, etc. Release site $1=$ Henningsen-Lotus, 2 =Camp Lotus. Telemetry error is mean $\pm \mathrm{SE}$. Fish ID superscripts (G1-3) denote release groups

Fish ID Release Site Telemetry Error (m) Tracking Dates for EMG transmittered Fish

\begin{tabular}{|c|c|c|c|c|c|c|c|c|c|c|c|c|c|c|c|c|c|c|c|c|}
\hline & & & Aus & ust & & & & ten & ber & & & & & & tob & & & & & \\
\hline & & & 26 & 29 & 30 & 31 & 7 & 9 & 12 & 13 & 14 & 19 & 27 & 3 & 4 & 18 & 19 & 20 & 24 & 25 \\
\hline RTE $1^{\mathrm{G} 1}$ & 1 & $14.7 \pm 1.4$ & 1 & & & 2 & 3 & & & & & & & & & & & & & \\
\hline RTE $2^{\mathrm{G} 1}$ & 1 & $20.7 \pm 2.8$ & 1 & & & & & 2 & 3 & & & 4 & & & & & & & & \\
\hline RTE $3^{\mathrm{G} 1}$ & 2 & $15.8 \pm 1.8$ & & 1 & & & & 2 & 3 & & & 4 & & & & & & & & \\
\hline $\operatorname{RTE} 4^{\mathrm{G} 1}$ & 2 & $15.0 \pm 1.2$ & & & 1 & & & & & 2 & 3 & & & & & & & & & \\
\hline RTE $5^{\mathrm{G} 1}$ & 1 & $9.1 \pm 0.1$ & & & & & & & & & & & 1 & 2 & 3 & & & & & \\
\hline RTE $6^{\mathrm{G} 2}$ & 1 & $8.3 \pm 0.3$ & & & & & & & & & & & & & & 1 & 2 & 3 & & 4 \\
\hline RTE $7^{\mathrm{G} 3}$ & 1 & $10.5 \pm 0.3$ & & & & & & & & & & & & & & 1 & 2 & 3 & 4 & \\
\hline RTE $8^{\mathrm{G} 3}$ & 1 & $10.4 \pm 0.9$ & & & & & & & & & & & & & & 1 & 2 & $3^{a}$ & & \\
\hline RTE $9^{\mathrm{G} 3}$ & 1 & $10.4 \pm 1.6$ & & & & & & & & & & & & & & $1^{\mathrm{b}}$ & & & & \\
\hline
\end{tabular}

${ }^{\text {a }}$ RTE 8 moved out of detection range as the water level increased on 20 October 2005

${ }^{\mathrm{b}}$ RTE 9 was not detected after the release day, despite attempts to locate it upstream and downstream within the study reach

stages of a day's pulsed cycle (pre- pulse, increasing flow, peak, and decreasing flow) for 5-10 h (mean: 8 h). River flows were low (e.g., $5 \mathrm{~m}^{3} \mathrm{~s}^{-1}$ ) during the pre-pulse stage, and on days when no flow pulse was produced. During the flow pulse's second stage (typically lasting 2-4 h) additional water was released from Chili Bar Dam and water velocity and level increased rapidly. The water level remained high during the third (peak) stage $(2-4 \mathrm{~h})$. Flows typically peaked at $40 \mathrm{~m}^{3} \mathrm{~s}^{-1}$, although peaks in the 80 $100 \mathrm{~m}^{3} \mathrm{~s}^{-1}$ range (e.g., for whitewater rafting) were also experienced (Fig. 1). During the fourth stage (1-2 h,

Table 2 The number of day and night pulsed-flow peaks each week during the EMG telemetry study

\begin{tabular}{lll}
\hline Date & \multicolumn{2}{l}{ Pulsed Flows (\#/week) } \\
\cline { 2 - 3 } & Day & Night \\
\hline Aug 25-31 & 7 & 4 \\
Sept 1-7 & 7 & 4 \\
Sept $8-14$ & 7 & 2 \\
Sept $15-21$ & 5 & 2 \\
Sept 22-28 & 3 & 2 \\
Sept 29-Oct 6 & 8 & 4 \\
Oct 7-13 & 7 & 3 \\
\hline
\end{tabular}

typically) flows, water levels, and velocities decreased to those observed in the pre-pulse stage. Although tracking efforts usually concentrated on one fish each day, the positions and EMG's of other EMGtransmitting trout were also recorded, if they were detected in the vicinity. Minimal movement rates of fish in the river were calculated from the measured distances and times between fish locations on successive tracking days.

Linear regressions from each fish's laboratory calibrations were used to convert median EMGs of fish in the river to estimated swimming speeds. The median speed was based on EMG measurements recorded during each 1 -h tracking interval. We developed a mixed-linear model to test the relationship between median swimming speed and fixed factors: 1) sex, 2) $U_{\text {crit }}$ 3) standard length, 4) mass, 5) river mile, 6) discharge, 7) pulse stage, 8) days in the river, and 9) rate of movement (alpha=0.05). A random effect was modeled for each fish to capture individual differences in activity. Time dependence was modeled using a repeated-measures analysis with compound symmetry structure for each fish by date combination. Residuals were examined to assess model fit. Analyses and data plotting were performed using Minitab ${ }^{\circledR}$ Release 14, SAS/STAT ${ }^{\circledR}$, Sigmastat ${ }^{\circledR}$ 3.0, and Sigmaplot ${ }^{\circledR} 8.0$ software packages. 
Fig. 1 River flow or discharge from Chili Bar Dam during the EMG telemetry studies in the South Fork of the American River

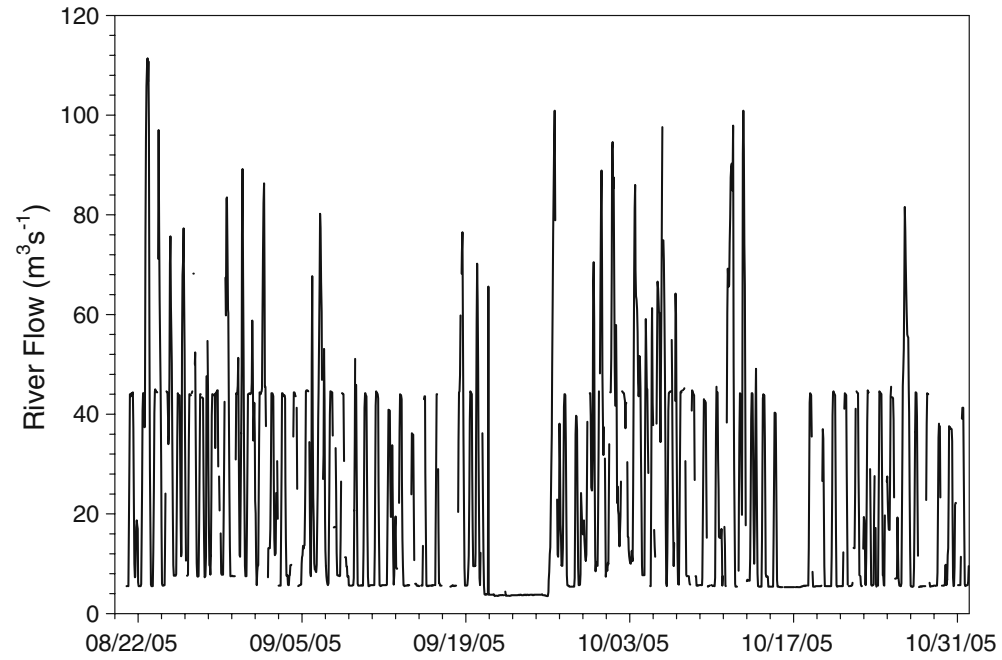

\section{Results}

Laboratory swimming experiments

The mean $\mathrm{U}_{\text {crit }}$ of rainbow trout with transmitters were statistically indistinguishable from those of trout without transmitters (mean \pm SE: $70.6 \pm 3.8$ and $79.7 \pm$ $2.3 \mathrm{~cm} \mathrm{~s}^{-1}$, respectively; $p=0.180$, ANOVA), although fish with transmitters were longer and heavier $(p=0.037$ and $p=0.018$ respectively, one-way ANOVA). Because the $\mathrm{U}_{\text {crit }}$ of trout carrying transmitters did not differ between the water temperature groups ( $p=0.097, t$-test), the data were combined for further comparisons. The fish carrying transmitters and released into the river had a mean $\mathrm{U}_{\text {crit }}$ of $70.6 \mathrm{~cm} \mathrm{~s}^{-1}$ ( $\mathrm{SE} \pm 3.8 \mathrm{~cm} \mathrm{~s}^{-1}$, range: 60 to $94.9 \mathrm{~cm} \mathrm{~s}^{-1}$ ), and holding time prior to laboratory calibrations was not related to $\mathrm{U}_{\text {crit }}(p=0.0622$, Pearson Product Moment Correlation).

Similarly, the mean TBFs of tagged and untagged trout (mean range 83 to 203 strokes min $^{-1}$ ) did not differ significantly ( $p>0.05$; ANOVA), except at $65.9 \mathrm{~cm} \mathrm{~s}^{-1}$ where the TBFs of untagged fish were significantly faster (mean 25.8 strokes $\mathrm{min}^{-1}$ faster; $p=0.002$, oneway ANOVA, Holm Sidak post-hoc), versus the mean difference for the four other velocities (4.35 strokes $\min ^{-1}$ ). The TBFs of both tagged and untagged trout increased significantly $(p<0.001$; one-way ANOVA, Holm Sidak post-hoc) at each of the velocity steps except that the TBFs of tagged fish at the $52.6 \mathrm{~cm} \mathrm{~s}^{-1}$ and $65.9 \mathrm{~cm} \mathrm{~s}^{-1}$ steps were indistinguishable $(p=0.452$, one-way ANOVA, Holm-Sidak post-hoc).
The $\mathrm{U}_{\text {crit }}$ means were not statistically distinguishable among the three release groups $(p=0.248$, oneway ANOVA), although fish in groups 2 and 3 were significantly heavier than fish in group $1(p=0.006$, one-way ANOVA, Tukey tests). As the water velocity increased in the Brett type-swimming chamber, swimming speeds and the EMG values increased linearly for all of the fish, albeit with some overlap of EMG values between the velocity steps (Fig. 2). Trout TBF also increased with increasing swimming speed $\left(y=35.855+1.923 \mathrm{x}, \mathrm{r}^{2}=0.9913\right.$; Fig. 3$)$.

The oxygen consumed by trout increased with increased swimming speed at both temperatures (Fig. 3), with the following regression relationships: $y=316.775+3.393 \mathrm{x}, \mathrm{r}^{2}=0.842$ (group 1); $y=-1.559+$ $5.763 \mathrm{x}, \mathrm{r}^{2}=0.987$ (group 2); and $y=-213.128+$ $14.063 x, r^{2}=0.977$ (group 3). Similarly, the laboratory oxygen consumption rates increased with increased EMG values for fish with both transmitter types: $y=$ $90.594+45.081 \mathrm{x}, \mathrm{r}^{2}=0.9860$ (group 1); $y=-659.975+$ $55.434 \mathrm{x}, \mathrm{r}^{2}=0.9906$ (groups 2 and 3, Fig. 4). The latter regressions were used for subsequent conversions of field EMGs into estimated oxygen consumption rates.

Field study

Except for RTE 2 and 4, the trout remained within $1 \mathrm{~km}$ of the release site during the study (Fig. 5). Movement rates during our tracking measurements were $27.9 \pm 3.9 \mathrm{~m} \mathrm{~d}^{-1}$ (mean $\pm \mathrm{SE}$ ). Trout RTE 2 and 4 moved $>1.5 \mathrm{~km}$ downstream from the Camp Lotus 
Fig. 2 Mean $( \pm$ SD) electromyograms (EMGs) recorded at increasing swimming speeds for release group 1 (RTE 1-5) at $19^{\circ} \mathrm{C}$ and release groups 2 (RTE 6) and 3 (RTE 7-9) at $16^{\circ} \mathrm{C}$ in a Brett styleswimming chamber. $\bullet$ RTE $1 \mathrm{r}^{2}=0.6275$, RTE $2 \mathrm{r}^{2}=$ $0.7961, \Delta$ RTE $3 r^{2}=$ $0.8086, \boldsymbol{\nabla}$ RTE $4 \mathrm{r}^{2}=$ 0.8548 , RTE $5 \mathrm{r}^{2}=0.8913$, ○ RTE $6 r^{2}=0.6007$, $\square$ RTE $7 \mathrm{r}^{2}=0.7895, \Delta$ RTE $8 \mathrm{r}^{2}=$ 0.8530 , and $\diamond$ RTE $9 \mathrm{r}^{2}=$ 0.6085

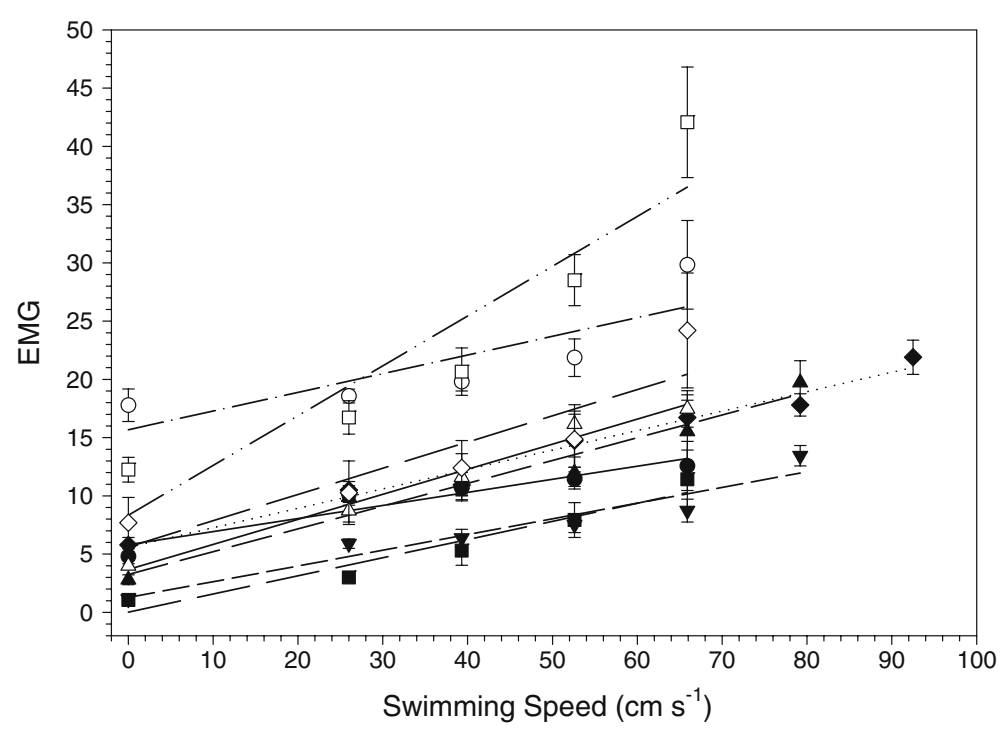

release site, and then remained within a $0.5-\mathrm{km}$ reach. Although there was a trend of increasing distance downstream from the release location with increasing time in the river $(95 \pm 44 \mathrm{~m}$ [mean $\pm \mathrm{SE}$ ] on release day, $308 \pm 131 \mathrm{~m}$ after $7 \mathrm{~d}$, and $980 \pm 324 \mathrm{~m}$ after $14 \mathrm{~d}$ ), rates of movement within the river were not correlated with river flow or river pulse stage. Total daily movements during EMG tracking days were higher on the release days (median: $235 \mathrm{~m}$ ), than on subsequent days (median: $52 \mathrm{~m}$; Mann-Whitney Rank Sum Test $p=0.023$ ). During our tracking, fish were located in the main channel $57.0 \%$ of the time, followed by river side margins $(41.5 \%)$, and backwater areas $(1.5 \%)$.
Of the fixed factors in the mixed-linear model to predict median swimming speed, only increasing pulse stage was statistically significant ( $F$-test, $p=0.0002$, Table 3). There were no second-order interactions, and very little explanatory power was lost in the reduced model when the non-significant factors were eliminated. Pulse stage was still statistically significant in the reduced model ( $F$-test, $p=0.0001$, Fig. $6 \mathrm{a}$ and $\mathrm{b}$ ). The second (increasing flow) pulse stage was associated with the largest mean swimming speed increase $\left(+17.5 \mathrm{~cm} \mathrm{~s}^{-1}\right)$, compared with the pre-pulse swimming speed, despite the pulsed-stage-specific median swimming speeds for the shorter (SL $35.0 \mathrm{~cm} \pm 1.5 \mathrm{SE}$ ) and lighter (967.3 $\mathrm{g} \pm 125.4 \mathrm{SE}$ ) group 1 fish being
Fig. 3 Mean \pm SE oxygen consumption rate $\left(\mathrm{MO}_{2}\right)$ and tailbeat frequency of the three groups of rainbow trout when exposed to increasing water velocities in the laboratory

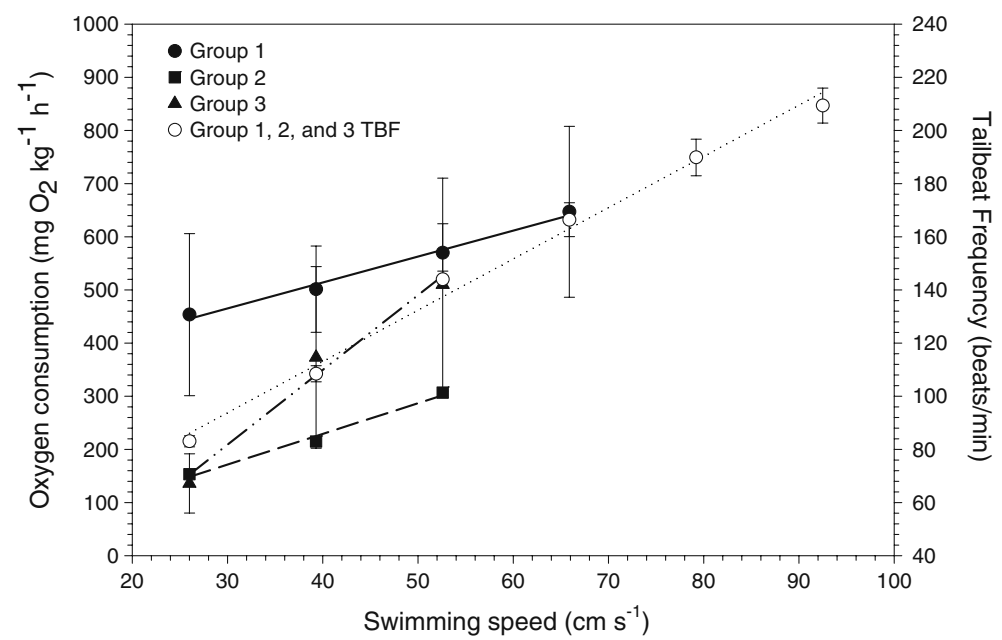


Fig. 4 Mean $( \pm \mathrm{SE})$ plot model of oxygen consumption versus EMG $( \pm \mathrm{SE})$ output for the different transmitter types $(5-\mathrm{s}$, group 1; 2-s, groups 2 and 3) from laboratory calibrations

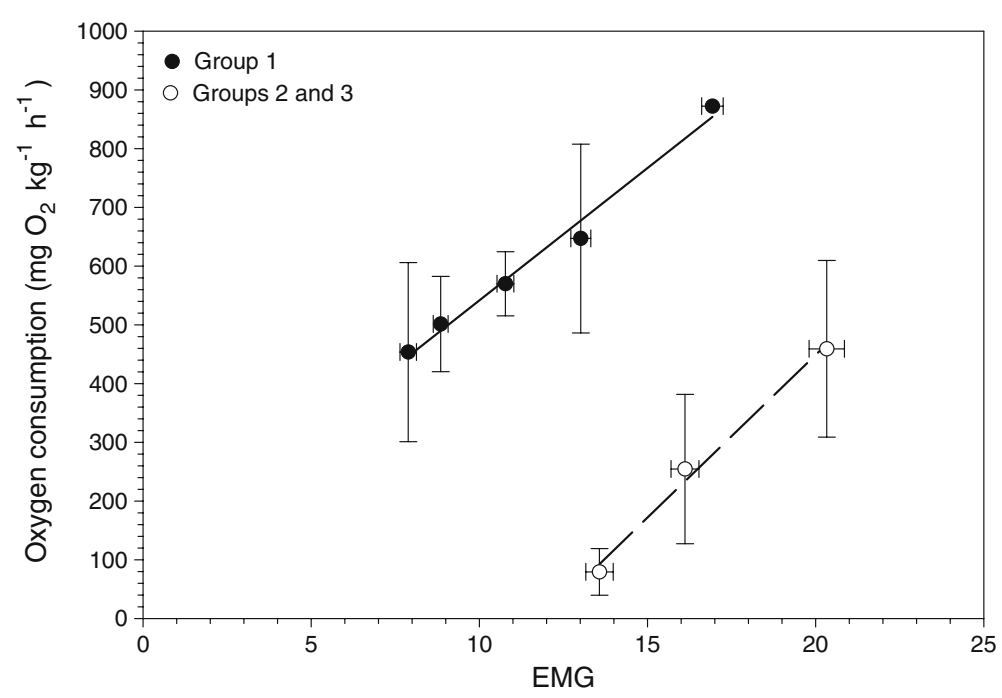

approximately half those of groups 2 and 3 fish (SL $44.4 \mathrm{~cm} \pm 0.9 \mathrm{SE} ; 1932.3 \mathrm{~g} \pm 111.8 \mathrm{SE}$; Mann-Whitney Rank Sum Test $p \leq 0.002$ ). Based on the laboratory calibrations, mean oxygen consumption rates of all three groups increased by an overall mean difference of $239 \mathrm{mg} \mathrm{O} \mathrm{Kg}^{-1} \mathrm{~h}^{-1}$, from the pre-pulse to the increasing pulse stage (group 1 and groups 2 and 3 , one-way ANOVA Tukey tests, $p<0.001$ ). Also, group 1 mean oxygen consumption rate remained elevated during the decreasing pulse stage, compared with the pre-pulse stage (one-way ANOVA Tukey tests, $p<$ 0.001 , Fig. $6 \mathrm{c}$ and d).
Although the relationship between swimming speed and river discharge was not significant there appears to be a threshold river flow of $44 \mathrm{~m}^{3} \mathrm{~s}^{-1}$, above which the trout swimming speed and activity decreased (Fig. 7a and b). Even though group 3 fish never experienced flows $>44 \mathrm{~m}^{3} \mathrm{~s}^{-1}$, both groups 1 and 2 experienced several water discharge peaks $>75 \mathrm{~m}^{3} \mathrm{~s}^{-1}$. The mean ( \pm SE) swimming speed of group 1 and 2 fish was $26.60 \mathrm{~cm} \mathrm{~s}^{-1}( \pm 1.65)$ in flows up to $44 \mathrm{~m}^{3} \mathrm{~s}^{-1}$, significantly faster than that above the threshold flow $\left(17.49 \pm 2.35 \mathrm{~cm} \mathrm{~s}^{-1}, p=0.010\right.$, one-way ANOVA). Also, the mean $( \pm \mathrm{SE})$ fish movement rate of group 1
Fig. 5 The distance from the release location of EMG transmitter trout located during tracking, with negative values indicating downstream locations. Group 1 fish (RTE 1-5), group 2 fish (RTE 6), and group 3 fish (RTE 7-9). Open symbols represent fish released at Camp Lotus, closed symbols represent fish released at HenningsenLotus Park. RTE 9 is omitted from the figure because it was not relocated a second time

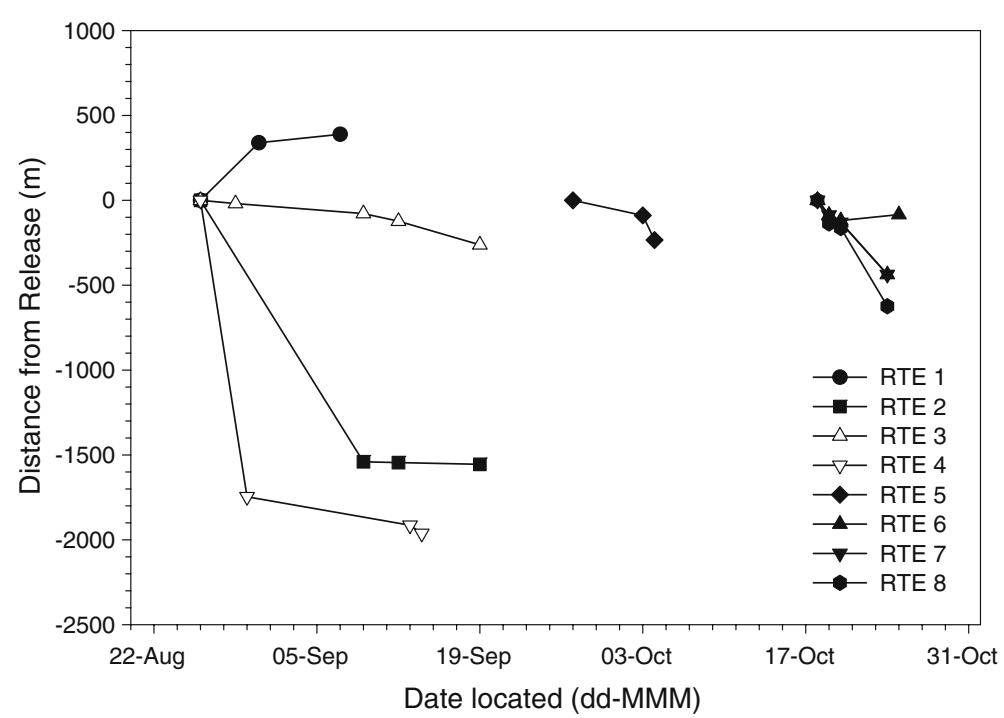


Table 3 Mixed model analysis results evaluating the factors potentially related to swimming speed during the EMG field studies, including degrees of freedom (DF), F statistic (F), and $P$ value $(\mathrm{P})$

\begin{tabular}{|c|c|c|c|c|}
\hline Factors & $\mathrm{DF}$ & $\mathrm{F}$ & $\mathrm{P}$ & Significant $\alpha \leq 0.05$ \\
\hline Sex (male, female, unknown) & 2 & 0.03 & 0.9700 & No \\
\hline $\mathrm{U}_{\text {crit }}\left(\mathrm{cm} \mathrm{s}^{-1}\right)$ & 1 & 1.17 & 0.2796 & No \\
\hline Standard length $(\mathrm{cm})$ & 1 & 0.75 & 0.3887 & No \\
\hline Weight $(\mathrm{g})$ & 1 & 0.54 & 0.4650 & No \\
\hline River kilometer (km) & 2 & 2.44 & 0.0890 & No \\
\hline Discharge $\left(\mathrm{m} 3 \mathrm{~s}^{-1}\right)$ & 1 & 0.67 & 0.4135 & No \\
\hline Pulse stage (Pre-Pulse, Increasing, Peak, Decreasing) & 3 & 6.95 & 0.0002 & Yes \\
\hline Days in the river $(\mathrm{d})$ & 1 & 0.34 & 0.5628 & No \\
\hline Rate of movement $\left(\mathrm{m} \mathrm{h}^{-1}\right)$ & 1 & 0.06 & 0.8031 & No \\
\hline
\end{tabular}

and 2 fish was $36 \mathrm{~m} \mathrm{~h}^{-1}( \pm 8.36)$ in flows up to $44 \mathrm{~m}^{3} \mathrm{~s}^{-1}$, significantly faster than that above the threshold flow $\left(5.47 \pm 1.87 \mathrm{~m} \mathrm{~h}^{-1}, p<0.001\right.$, one-way ANOVA). Overall, fish swimming speeds recorded during field studies tended to be lower than their individual $\mathrm{U}_{\text {crit }}$ values, and fish rarely swam faster in the river than their maximum calibration velocity in the swim tunnel (Table 4).

\section{Discussion}

The South Fork of the American River is a flowregulated system where fish are challenged by changing flows on a daily basis. The pulses increase water velocities in the main channel and inundate flood plains, expanding habitat availability and complexity. Depending on the river morphology, this
Fig. 6 Plot a shows release group 1, and plot $\mathbf{b}$ shows release groups 2 and 3 median swimming speed for the four pulse stages, calculated from laboratory linear regressions for each fish, with * noting the significant pulse stage in the mixedlinear model. Plot $\mathbf{c}$ shows release group 1, and plot $\mathbf{d}$ shows release groups 2 and 3 median oxygen consumption rates, calculated from field EMGs using linear regressions from Fig. 2, for each transmitter type and pulse stage. Letters represent significantly different pulse stages. All plots are shown for the 10th, 25th, 75th, 90th percentiles with outliers for each river pulse level
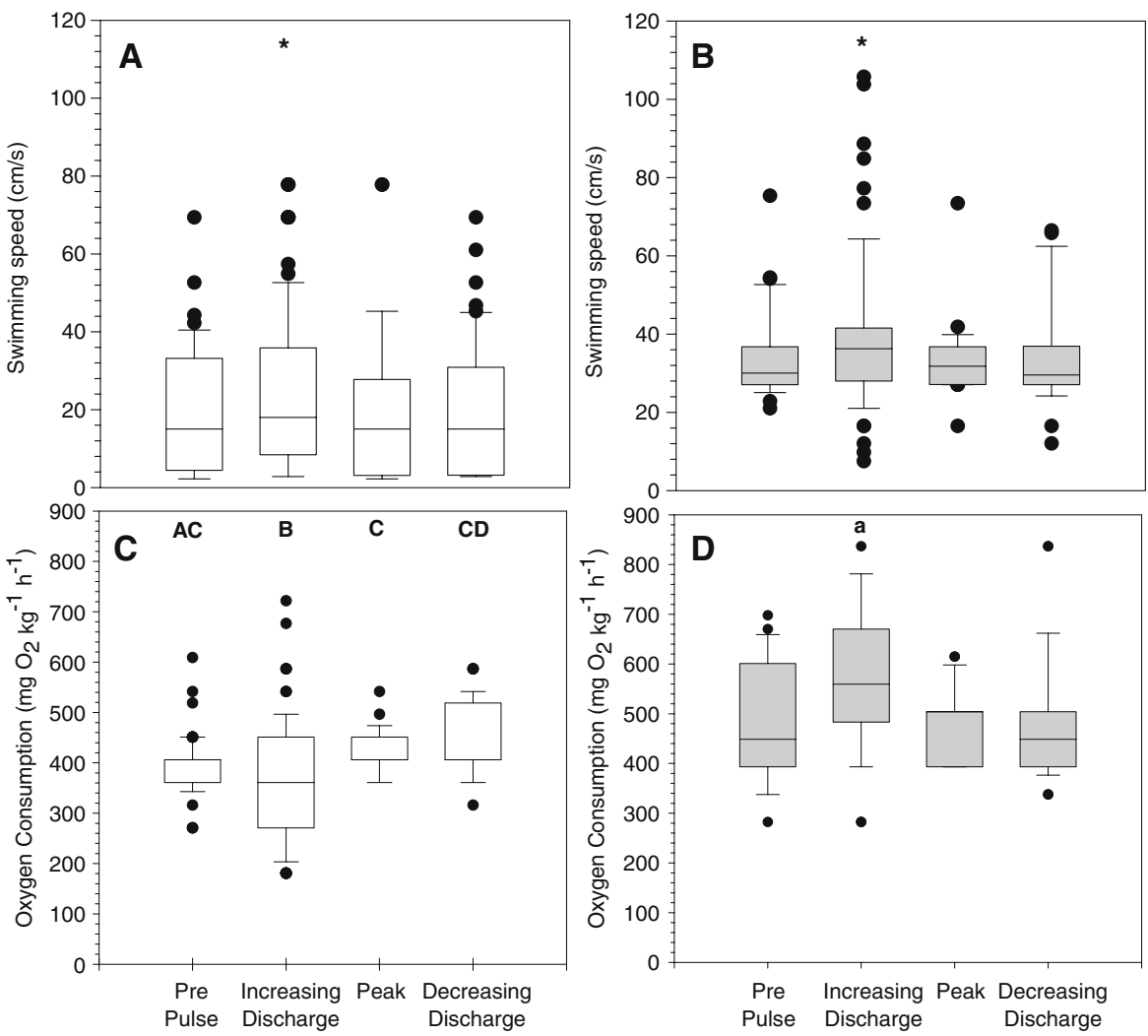
Fig. 7 a Swimming speeds of EMG-tagged trout, estimated from swimming speed-EMG regression, versus river flow, and $\mathbf{b}$ Rate of fish movement during tracking versus river flow. Group 3 fish never experienced flows over approximately $44 \mathrm{~m}^{3} \mathrm{~s}^{-1}$ (see

Fig. 1), whereas groups 1 and 2 experienced several flow peaks over $75 \mathrm{~m}^{3} \mathrm{~s}^{-1}$
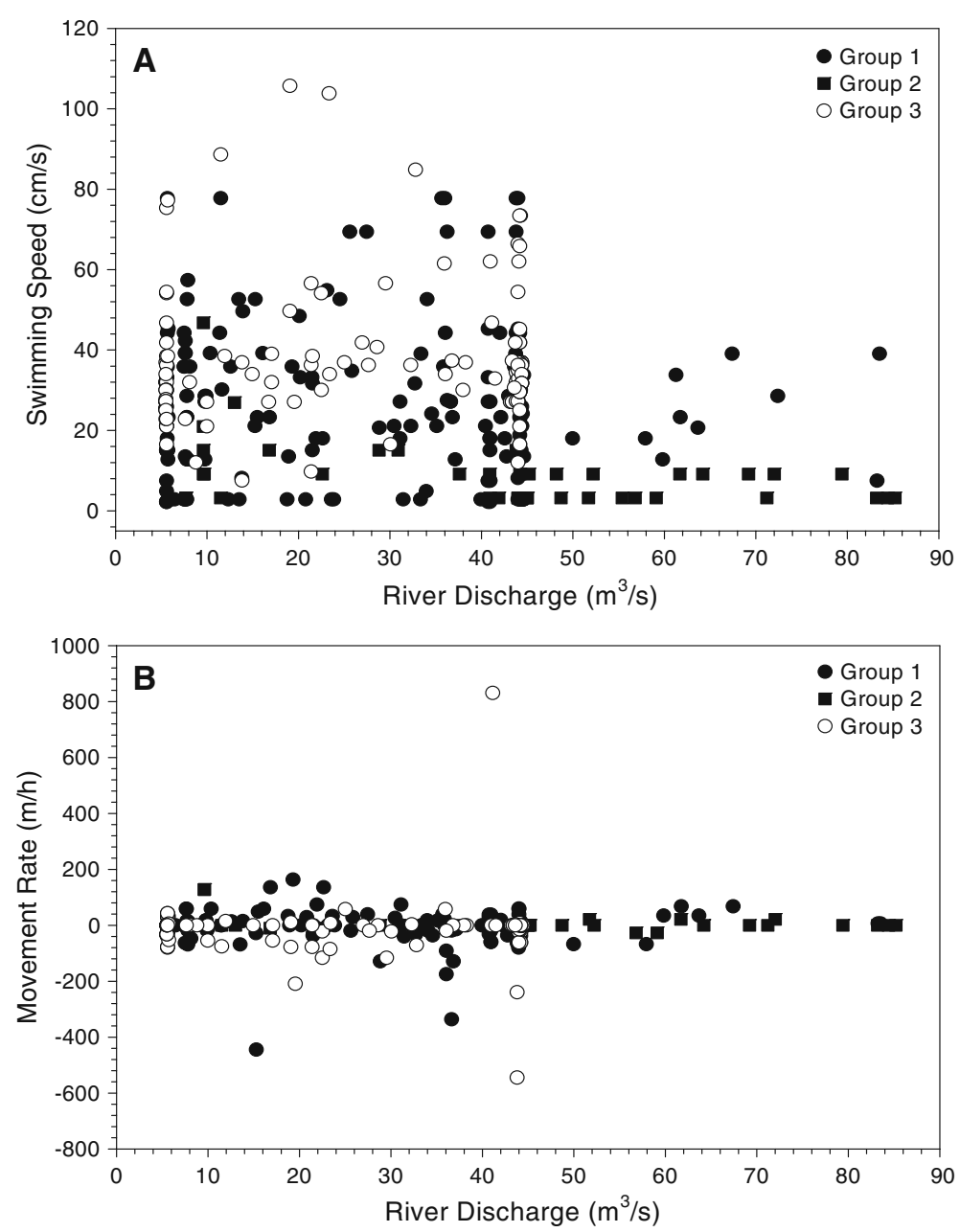

habitat expansion may occur in a non-linear manner (Mount 1995). The increased swimming speeds of rainbow trout during the increasing-flow stage probably resulted from the fish's tendency to maintain

Table 4 Mean ( \pm SE) percentage of EMGs from tagged rainbow trout, during different stages of hydroelectric pulse events, observed at velocities $<50 \%$ and $<100 \%$ of their critical swimming velocity, and percentage of trout that swam faster than their highest laboratory calibration speed during a given pulse stage

\begin{tabular}{lllc}
\hline Pulse stage & $\begin{array}{l}<0 \% \\
\text { Ucrit }\end{array}$ & $\begin{array}{l}<100 \% \\
\text { Ucrit }\end{array}$ & $\begin{array}{l}\text { >Highest calibration } \\
\text { speed }\end{array}$ \\
\hline Pre-Pulse & $62.5 \pm 11.4$ & $90.4 \pm 5.9$ & $7.5 \pm 4.4$ \\
Increasing Flow & $54.2 \pm 11.7$ & $86.0 \pm 8.5$ & $12.3 \pm 7.6$ \\
Peak & $62.7 \pm 10.8$ & $87.9 \pm 8.0$ & $9.6 \pm 6.1$ \\
Decreasing Flow & $63.0 \pm 10.9$ & $91.3 \pm 5.9$ & $6.3 \pm 3.9$ \\
\hline
\end{tabular}

position in streams (Vondracek and Longanecker 1993; Klimley et al. 2005; Klimley et al. 2007) near prime foraging locations (Moyle 2002). The dramatic swimming velocity and movement rate decreases above the $44 \mathrm{~m}^{3} \mathrm{~s}^{-1}$ discharge level were similar to those of brown trout (Salmo trutta) below a pulsed hydroelectric station, where water discharges increased the trout's use of cover, pools, and interstitial shoreline habitats (Bunt 1999). Our trout may have habituated to this discharge level, because most of the peak water discharges from Chili Bar Dam were close to $44 \mathrm{~m}^{3} \mathrm{~s}^{-1}$, with just occasional peaks well above this threshold. Presumably increased habitat complexity would diversify the available water velocities (Lisle 1986), and selection of slower velocities by fish would decrease energetic demands (Beamish 1978). Liao (2007) recently demonstrated that trout use energy from vortices in turbulent flows, a partially 
energy-conserving behavior. Some fish, however, may sustain increased swimming at peak flows. Murchie and Smokorowski (2004) recorded increased EMGs in walleye (Sander vitreus) and brook trout (Salvelinus fontinalis) as pulsed flows increased.

In the laboratory we found a difference between the two types of EMG transmitters used. The 2-s EMG transmitter was more sensitive in detecting and transmitting strenuous aerobic muscle activity than was the 5 -s transmitter. Although the two transmitters differed in size, with the larger transmitters in the larger fish, the gold-tipped electrodes were identical. Because of the proportionately larger red-muscle bands in the larger (release groups 2 and 3) fish, the detection of the voltage oscillations associated with muscular activity may have been more complete, increasing EMG signals, compared with those in the smaller fish (Beddow and McKinley 1999). Regardless, both transmitter types showed similar patterns of increasing TBF, swimming speed, and $\mathrm{MO}_{2}$ with increasing EMG signals. Because the transmitters were calibrated in the laboratory in their respective trout at field-appropriate temperatures, the time-averaging difference of redmuscle contractions did not decrease the usefulness of the data (Hinch and Rand 1998).

In our concurrent radio-tracking study (Klimley et al. 2007) the majority (17/20) of the rainbow trout remained in a small home area, after an initial movement upstream or downstream directly after release. This behavior was consistent with that of our fish carrying the EMG transmitters, as they responded to pulsed flows. The low rate of movement of EMG fish in the river during tracking (relatively constant, near $0 \mathrm{~m} \mathrm{~h}^{-1}$ ) suggests that the recorded changes in swimming speed with pulse stage are not explained by changes in location along the river. It appears that trout altered their behavior during the increasing pulsed flow stage by increasing their swimming velocity and staying in the same relative location. Trout with the EMG transmitters were not stimulated to initiate upstream spawning migration as may be predicted by their size and sexual maturity (several EMG tagged fish had distinguishable gonads nearing reproductive maturity). Gido et al. (2000) observed that during spring reservoir releases, 12 out of 17 radiotransmittered rainbow trout remained very close to their point of release. Our trout tended to move laterally during the larger discharge events (S.A. Hamilton, J. Miranda, and G. Jones, unpubl. observa- tions). Additionally, Klimley et al. (2005) found that radio-tagged adult rainbow trout and brown trout were not displaced downstream when subjected to a 1-d, 35fold increase in flow in Silver Creek, a tributary of the South Fork American River.

Geist et al. (2005) found that white sturgeon (Acipenser transmontanus) movements were restricted by high flows (192-836 $\mathrm{m}^{3} \mathrm{~s}^{-1}$ ), similar to our trout, which showed minimal longitudinal movement during flow pulses. In our concurrent (Klimley et al. 2007) radio-tracking study the largest upstream movements occurred during weeks of lower pulsed flows.

The observation that fish in the river swam above their highest calibration speed may indicate strenuous aerobic coupled with anaerobic activity. Based on the findings of Liao et al. (2003) regarding the use of vortices by fish, our rainbow trout may have been more active when seeking consistent vortices (e.g., generated by large in-river boulders) which would not be present during changing flows, but would have been present once flows peaked and stabilized. This could explain the decreased EMGs observed at the peak discharge pulse stage, compared with the increasing flow stage.

Because the electrodes are placed in the red (i.e., slow-oxidative) muscle bands, EMG telemetry is likely a much better measure of aerobic activity and consequent energetic demand (Briggs and Post 1997), than that of anaerobic activity, associated with contraction of white (i.e., fast glycolytic) muscles and burst swimming (Hinch and Rand 1998; Burgetz 1996). Our laboratory (aerobic) metabolic rate range of 509$646 \mathrm{mg} \mathrm{O}_{2} \mathrm{~kg}^{-1} \mathrm{~h}^{-1}$ for trout encompass Dickson and Kramer's (1971) findings for rainbow trout peak active metabolic rates of 570 and $592 \mathrm{mg} \mathrm{O}_{2} \mathrm{~kg}^{-1} \mathrm{~h}^{-1}$ at 15 and $20^{\circ} \mathrm{C}$, respectively. However, Briggs and Post (1997) estimated that the daily maximal metabolic rate of rainbow trout in a non-flowing, $300 \mathrm{~m}^{3}$ pond at $225 \mathrm{mg} \mathrm{O}_{2} \mathrm{~kg}^{-1} \mathrm{~h}^{-1}$, much less than we would predict from our laboratory results (Fig. 4).

An alternative explanation of our rainbow trout's increasing activity during pulse-induced flow increases is increased foraging in response to higher densities of drifting prey dislodged from the substrate by the increased discharge (Borchardt 1993, Salamunovich 2003). Increases in turbidity (e.g., from disturbance of river sediments and suspended invertebrates, some of which may be deposited on the floodplain after peak flows ([Salamunovich 2003], or from the reservoir providing the pulsed flow water) were also noted 
during the second stage (S.A. Hamilton unpubl. observation).

Bachman (1984) found that hatchery, compared with wild, brown trout spent more time traveling, and spent less time using "cost-minimizing features" of the substrate. Bohlin et al. (2002) also found hatchery and wild introduced brown trout moved more than wild residents. This suggests that even though we exercised our fish to have fitness similar to that of wild fish, we may have been observing an overestimation of energy expenditures for wild resident trout.

Future research on how prolonged small-amplitude pulses affect fish behavior over longer periods would be beneficial, to determine how food resources, daylight feeding time, and temperature fluctuations can alter trout behavior and energetics. Such investigations could include rivers with slower ramping rates of discharge, and with longer, more stable peak discharges.

Acknowledgements We thank D. Kratville, M. Fish, S. Chun, T. O'Rear, C. Woodley, and R. Kaufman for laboratory assistance; E. Hallen and P. Lutes (CABA) for fish-holding assistance; J. Braun for statistical assistance; D. Redfern and F. Harris of the American River Trout Hatchery for rainbow trout; B. and R. Center from Camp Lotus for valuable knowledge of the river; and the Division of Water Rights of the State Water Resources Control Board for consistent support. This study was funded by the Public Interest Energy Research (PIER) Program (Grant No. 500-01-044) of the California Energy Commission through the Pulsed Flow Program of the University of California, Davis.

Open Access This article is distributed under the terms of the Creative Commons Attribution Noncommercial License which permits any noncommercial use, distribution, and reproduction in any medium, provided the original author(s) and source are credited.

\section{References}

Bachman RA (1984) Foraging behavior of free-living wild and hatchery brown trout in a stream. Trans Am Fish Soc 113:1-32

Beamish FWH (1978) Swimming capacity. In: Hoar WS, Randall DJ (eds) Fish physiology, vol 7. Academic, New York, pp 161-187

Beddow TA, McKinley RS (1999) Importance of electrode positioning in biotelemetry studies estimating muscle activity in fish. J Exp Biol 54:819-831

Bohlin T, Sundström LF, Johnsson JI, Höjesjö J, Pettersson J (2002) Density dependent growth in brown trout: effects of introducing wild and hatchery fish. J Anim Ecol 71:683-692
Borchardt D (1993) Effects of flow and refugia on drift loss of benthic macroinvertebrates: implications for habitat restoration in lowland streams. Freshw Biol 29:221-227

Brett JR (1964) The respiratory metabolism and swimming performance of young sockeye salmon. J Fish Res Board Can 21:1183-1226

Briggs CT, Post JR (1997) In situ activity metabolism of rainbow trout (Oncorhynchus mykiss): estimates obtained from telemetry of axial muscle electromyograms. Can J Fish Aquat Sci 54:859-866

Brown RS, Geist DR (2002) The use of electromyogram (EMG) telemetry to assess swimming activity and energy use of adult Chinook salmon migrating through tailraces, fishways, and forebays of Bonneville Dam, 2000 and 2001. U.S. Army Corps of Engineers, Portland District, Portland, Oregon

Brown RS, Geist DR, Mesa MG (2006) Use of electromyogram telemetry to assess swimming activity of adult spring Chinook salmon migrating past a Columbia River dam. Trans Am Fish Soc 135:281-287

Bunt CM (1999) A tool to facilitate implantation of electrodes for electromyographic telemetry experiments. J Fish Biol 55:1123-1128

Bunt CM, Cooke SJ, Katopodis McKinley S (1999) Movement and summer habitat of brown trout (Salmo trutta) below a pulsed discharge hydroelectric generating station. Regul River 15:395-403

Burgetz IJ (1996) The role of anaerobiosis during sub-maximal swimming in salmonids. Dissertation, University of British Columbia

Cech JJ Jr (1990) Respirometry. In: Schreck CB, Moyle PB (eds) Methods for fish biology. American Fisheries Society, Maryland, pp 335-362

Cooke SJ, Thorstad EB, Hinch SG (2004) Activity and energetics in free-swimming fish: insights from electromyogram telemetry. Fish Fish 5:21-52

Dickson IW, Kramer RH (1971) Factors influencing scope for activity and active and standard metabolism of rainbow trout (Salmo gairdneri). J Fish Res Board Can 28(4):587-596

Dill WA, Cordone AJ (1997) History and status of introduced fishes in California, 1871-1996. California Department of Fish and Game, Fish Bulletin 178, Sacramento, California, USA

FERC (Federal Energy Regulatory Commission) (2008) Final environmental impact statement for hydropower license. Upper American River Hydroelectric Project, FERC Project No. 2101-084, California, Chili Bar Hydroelectric Project, FERC Project No. 2155-024, California. FERC/ FEIS-0216F, $692 \mathrm{p}$

Geist DR, Brown RS, Lepla K, Chandler JA (2002) Practical application of electromyogram radiotelemetry: the suitability of applying laboratory-acquired calibration data to field data. N Am J Fish Manage 22:474-479

Geist DR, Brown RS, Cullinan V, Brink SR, Lepla K, Bates P, Chandler JA (2005) Movement, swimming speed, and oxygen consumption of juvenile white sturgeon in response to changing flow, water temperature, and light level in the Snake River, Idaho. Trans Am Fish Soc 134:000-000

Gido KB, Larson RD, Ahlm LA (2000) Stream-channel position of adult rainbow trout downstream of Navajo Reservoir, New Mexico, following changes in reservoir release. N Am J Fish Manage 20:250-258 
Green EJ, Carritt DE (1967) New tables for oxygen saturation of seawater. J Mar Res 25:140-147

Hammer C (1995) Fatigue and exercise tests with fish. Comp Biochem Physiol 112A:1-20

Healey MC, Lake R, Hinch SG (2003) Energy expenditures during reproduction by sockeye salmon (Oncorhynchus nerka). Behaviour 140:161-182

Hinch SG, Rand PS (1998) Swim speeds and energy use of upriver-migrating sockeye salmon (Oncorhynchus nerka): role of local environment and fish characteristics. Can J Fish Aquat Sci 55:1821-1831

Hinch SG, Diewert RE, Lissimore TJ, Prince AMJ, Healey MC (1996) Use of electromyogram telemetry to assess difficult passage areas for river-migrating adult sockeye salmon. Trans Am Fish Soc 125:253-260

Jobling M (1994) Fish Bioenergetics. Chapman and Hall, London

Kaseloo PA, Weatherley AH, Lotimer J, Farina MD (1992) A biotelemetry system recording fish activity. J Fish Biol 40 (22): 165-179

Klimley AP, Cech, Jr JJ, Thompson LC, Hamilton S, Chun SN (2005) Experimental and field studies to assess pulsed, water-flow impacts on the behavior and distribution of fishes in California rivers, annual report, 2004-05. Prepared for the PIER Program Area, California Energy Commission. 107 p. http://www.energy.ca.gov/publications/displayOneReport. php?pubNum=CEC-500-2005-172

Klimley AP, Cech, Jr JJ, Thompson LC, Hamilton S (2007) Experimental and field studies to assess pulsed, water flow impacts on the behavior and distribution of fishes in the South Fork of the American River, II (Second Year). University of California, Davis, for the California Energy Commission, PIER Energy-Related Environmental Research. $85 \mathrm{p}$

Lankford SE, Adams TE, Miller RA, Cech JJ Jr (2005) The cost of chronic stress: impacts of a nonhabituating stress response on metabolic variables and swimming performance in sturgeon. Comp Biochem Physiol A: Mol Integ Physiol 135(291):302

Lisle TE (1986) Effects of woody debris on anadromous salmonid habitat, Prince of Wales Island, Alaska. North Am J Fish Manage 6:538-550

Liao JC (2007) A review of fish swimming mechanics and behavior in altered flows. Phil Trans R Soc B 362:1973-1993

Liao JC, Beal DN, Lauder GV, Triantafyllou MS (2003) Fish exploiting vortices decrease muscle activity. Science 302:1566-1569

Mount JF (1995) California Rivers and streams: the conflict between fluvial process and land use. University of California Press
Moyle PB (2002) Inland fishes of California. University of California Press

Murchie KJ, Smokorowski KE (2004) Relative activity of Brook trout and Walleyes in response to flow in a regulated river. North Am J Fish Manage 24:1050-1057

PGE (Pacific Gas and Electric) (2005) Water temperature technical report. Sacramento Municipal Utility District Upper American River Project (FERC Project No. 2101) and Pacific Gas and Electric Company Chili Bar Project (FERC Project No. 2155). May 2005, version 5. 243 p

Prince A, Low S, Lissimore T, Diewert R, Hinch S (1995) Sodium bicarbonate and acetic acid: an effective anesthetic for field use. North Am J Fish Manage 15:170-172

Quintella BR, Andrade NO, Koed A, Almeida PR (2004) Behavioral patterns of sea lampreys' spawning migration through difficult passage areas, studied by electromyogram telemetry. J Fish Biol 65:961-972

Salamunovich T (2003) Rock Creek-Cresta (FERC No. 1962) recreation and pulse flow biological evaluation: stranding and displacement studies. Draft report of Thomas R. Payne and Associates, Arcata, CA to Pacific Gas and Electric Company, San Ramon, CA

Standen EM, Hinch SG, Healey MC, Farrell AP (2002) Energetic costs of migration through the Fraser River Canyon, British Columbia, in adult pink (Oncorhynchus gorbuscha) and sockeye (Oncorhynchus nerka) salmon as assessed by EMG telemetry. Can J Fish Aquat Sci 59:1809-1818

Sullivan GH, Hoefener C, Bolie VW (1963) Electronic systems for biological telemetry. In: Slater LE (ed) Bio-telemetry: the use of telemetry in animal behaviour and physiology in relation to ecological problems. Pergamon Press, London, pp 83-106

Thorstad EB, Okland F, Koed A, McKinley RS (2000) Radiotransmitted electromyogram signals as indicators of swimming speed in lake trout and brown trout. J Fish Biol 57:547-561

Vondracek B, Longanecker DR (1993) Habitat selection by rainbow trout Oncorhynchus mykiss in a California stream: implications for the instream flow incremental methodology. Ecol Freshw Fish 2:173-186

Weatherley AH, Rogers SC, Pincock DG, Patch JR (1982) Oxygen consumption of active rainbow trout, Salmo gairdneri Richardson, derived from electromyograms obtained by radiotelemetry. J Fish Biol 20(4):479-489

Webb PW (1971) The swimming energetics of trout. II. Oxygen consumption and swimming efficiency. J Exp Biol 55:521-540 